\title{
Rice and Spicy Diet: Author's Reply
}

TO THE EDITOR: I appreciate the comments from Wiwanitkit. I agree with him that there are many kinds of rice in the world and whether this difference leads to different reaction to the gastrointestinal tract (GI) has not been known. The nutritional composition of rice varies depending on its variety and growing condition. Although, the quantity of its major nutrient contents such as protein, lipid, carbohydrate and fiber are not much different between rice varieties in milled $^{1}$ or un-milled rice, ${ }^{2}$ this could not translate into the same effect of different rice varieties to the human GI tract.

I also agree that spicy is a subjective term and the degree of spicy is difficult to measure but the effects of spicy foods are likely to be the effects of its capsaicin content, which is measurable. ${ }^{3-7}$ Therefore, the degree of spicy may not be important as the quantity of capsaicin contents. I admit the fact that Asian people usually eat different combinations of mixed foods and their effect to the GI tract of patients with functional gastrointestinal disorders (FGID) is difficult to predict. Although, research studies on the effect of chili ingestion with different meals ${ }^{5,7}$ demonstrated consistent results on abdominal burning and pain, this cannot translate to the similar results when it is consumed with other specific food mixtures.

It has been reported that the amount of rice consumption per person/year in Japan, Korea and Thailand was decreasing ${ }^{8}$ from $89 \mathrm{~kg}, 119 \mathrm{~kg}$ and $152 \mathrm{~kg}$ during 1970-1972 to $65 \mathrm{~kg}, 104 \mathrm{~kg}$ and $110 \mathrm{~kg}$ during 1989-1991 and $59 \mathrm{~kg}, 88 \mathrm{~kg}$ and $109 \mathrm{~kg}$ during 1999-2001, respectively. The decrease consumption of rice should draw the attention of Asian doctors to the effect of rice in health, which has been neglected for several decades. I have shown evidences that rice seems to provide benefit for patients with FGID. ${ }^{3}$ FGID is one of the most common health problems in population around the world and many patients with FGID do not consult their doctors. Therefore rice should be advocated as the major source of carbohydrate not only in patients who come to doctors' clinic but also in the general population. Future research studies should focus not only the effect of rice on GI tract but also on the other organ systems. In addition, the appropriate amount of rice consumption per person/year should be studied.

Sutep Gonlachanvit, MD

Gastrointestinal Motility Research Unit Department of Internal Medicine Chulalongkorn University Bangkok, Thailand

1. Khatoon N, Prakash J. Nutritional quality of microwave and pressure cooked rice (Oryza sativa) varieties. Food Science Technol Intern 2006;12:297-305.

2. Rice and human nutrition. www.fao.org/rice2004/en/e-001.htm. 2004. Food and Agriculture Organization of the United Nations. 30-6-2010.

3. Gonlachanvit S. Are rice and spicy diet good for functional gastrointestinal disorders? J Neurogastroenterol Motil 2010;16:131-138.

4. Gonlachanvit S, Fongkam P, Wittayalertpanya S, Kullavanijaya P. Red chili induces rectal hypersensitivity in healthy humans: possible role of 5HT-3 receptors on capsaicin-sensitive visceral nociceptive pathways. Aliment Pharmacol Ther 2007;26:617-625.

5. Gonlachanvit S, Mahayosnond A, Kullavanijaya P. Effects of chili on postprandial gastrointestinal symptoms in diarrhoea predominant irritable bowel syndrome: evidence for capsaicin-sensitive visceral nociception hypersensitivity. Neurogastroenterol Motil 2009;21:23-32.

6. Bortolotti M, Coccia G, Grossi G, Miglioli M. The treatment of functional dyspepsia with red pepper. Aliment Pharmacol Ther 2002;16:1075-1082.

7. Lee KJ, Vos R, Tack J. Effects of capsaicin on the sensorimotor function of the proximal stomach in humans. Aliment Pharmacol Ther 2004;19:415-425.

8. Mahabub Hossain. Long-term prospects for the global rice economy. www.fao.org/rice2004/en/e-001.htm. 2004. Food and Agriculture Organization of the United Nation. 30-6-2010.

\section{Conflicts of interest: None.}

